\title{
Intellectual Capital of Enterprises and Its Role in the Integral Process
}

\author{
Tatiana Belyakova \\ High Economic School, St. Peterburg, Russia \\ finbelta@mail.ru
}

\begin{abstract}
In August 2012 Russia entered the World Trade organization (WTO) and took all the obligations on establishment of this organization according to the Marrakesh agreement. As a participant of the international trade system, Russia obtains a legitimate access to a very much unified legal space and international legal protection guaranteed by WTO norms, which should finally promote development of Russian foreign trade and Russian interests abroad. Thus, annually, within the framework of the world trade, economic participant benefit from application of simplified customs procedures $\$ 900 \mathrm{bn}$. Within Russia, according to the data of the Economic Cooperation and Development organization, this benefit may be $\$ 18$ bn. concerning protection of rights of intellectual property, the Russian Federation has not taken any additional obligations, - and During the period of negotiations the national legislative base was brought in line with the WTO norms. This article is going to consider questions of creation and usage of the intellectual capital in export-oriented innovative enterprises related to development of science and high-technology production, exportation of developed technologies and high-tech products.
\end{abstract}

Keywords: WTO organization, intellectual capital, innovation, high technology enterprise, scientific and technical progress

\section{Introduction}

Globalization changes the world and the people leading to the change of the character of in the markets, poorly controllable liberalization of financial markets, decreasing leverage efficiency in the sphere of social consciousness (family, school, company employees etc.). This is largely connected with emergence and development of so-called post-industrial society in the advanced countries of the world. On the one hand, it is characterized by deep technological transformation of the economy on the basis of the new knowledge immediately transformed into goods and services providing comfortable and prosperous livelihoods of the society. On the other hand, along with the increase of the economic constituent, this society is characterized by permanent consumption of spiritual and cultural benefits. From the economic point of view, it is science that plays a pivotal role in creation of the company value and provides company competitiveness in the postindustrial society. Scientific knowledge being the basis of most intangible assets of a company largely determines its competitiveness in the domestic and international markets. It is lawful to assert that intellectual property and the objects thereof are of principle importance for innovational development of the economy of a country and its competitiveness in the global world.

\section{The conception of intellectual capital (IC)}

Under these conditions the concept of intellectual capital (IC) becomes extremely topical. Daum (2002) states, that IC is a complex category based on the knowledge that may be formalized, estimated and managed by company ${ }^{1}$. Stewart (1991) defines IC as the aggregate of personnel's knowledge, information, experience, qualification and motivation, organization capacities, channels and communication technologies capable of creating the value-added and providing competitive advantages to commercial organizations in the market. This general and complex character of the term induced development of its various aspects, various approaches to defining IC, various classification's principles. ${ }^{2}$ Further research (Roos, Pike, \& Fernstrem, 2008) appropriate to focus on the classification IC and suggest subdividing IC according to its economic content into three categories ${ }^{3}$

\footnotetext{
${ }^{1}$ Daum J. H. Intangible Assets. Bonn: Galileo Press. GmbH, 2002.

2 Stewart T. Brainpower. // Fortune 1991.3 June.

3 J. Roos, S. Pike, L. Fernstrem. Intellectual capital, management practice. SPb, "High School of management", published by SPb University, 2008.
} 
Relationship capital: implies all the relations established by the organization with the environment (clients, suppliers, consumers, owners, creditors etc.). The relationship resources are neither owned, nor controlled by the organization. It can only influence them;

Organization capital: includes resources providing the market positions of the organization and its competitiveness. These are technologies, management systems, hardware and software, organizational structures, patents, brands. Organization capital belongs to and is controlled by the organization. It may be sold though in inefficient markets.

Human capital: includes the resources which characterize personal qualities of the personnel, which may not be replaced by machines or have a material form, for example, competence, skills, attitude to work, personal links etc. They do not belong to but are controlled by the individual.

These resources interact with each other creating the base for increasing the company value and its competitive advantage. Thus, interaction between the human and relationship capital increases competence of the company workers, which can occur first of all as a result of direct contacts with the consumer. Therefore, man organizations increase the number of workers having direct contacts with clients, since the feedback can increase the workers' qualification and improve the company image. As a result of interaction of the human and organization capital a significant part of individual knowledge in the form of approaches, principles, structural decisions included in the company database becomes accessible to all the company workers, which make it possible to provide on-the-job training and makes the company less dependent on the environment. On the other hand, if an organization invests significant sums in modern information technologies but does not support them with measures on creation of human and organization capital, the capital investments may appear to be ineffective. Nowadays Russia possesses considerable human capital but has not created sufficient organization and relationship capital, which makes the aggregate IC lower than it could be. Compared to traditional resources, usage of IC is characterized by a series of specifics features. In accordance with Stewart' conception (2007), the most important of its are the following:

- The size of IC does not decrease when used, but not necessarily increase in the case of additional investing, i.e. it does not possess the additional property;

- Three forms of IC resources are characterized by a nonlinear dependence of income on scale, do not follow the model of diminishing returns and are not necessarily owned or controlled by the organization;

- IC resources can be simultaneously used for performing various tasks; they are not alternative, for example, a specialist in some sphere can simultaneously solve professional problems and work at his country house;

- There are relatively high levels of information asymmetry in IC usage, which means that consumer's uncertainty with respect to the volume and quality of the resources; there is a difficulty in IC estimation, and therefore, there are no really efficient IC markets. ${ }^{4}$

At the same time it should be noted that there is a similarity in functioning of IC and physical capital. Thus, both kinds of capital result from investing funds, yield profit to their possessor, are subject to obsolescence and require maintenance. It is important to approve these theoretical provisions, since various behavioral characteristics of IC resources determine various economic behavior and, therefore, various logics of creation of the value for many major companies and organizations. Integrated management of the appropriate resources makes the base for reaching competitive advantage by companies with high dependence on IC resources. The scientific knowledge underlying many objects of intellectual capital including inventions play an important role in development of competition of the subjects of economic activity leading to evolution. The experience of the most successful economies confirms that intellectual resources are of key importance for innovational development of the national economy and its competitiveness in the modern global world. Russia is on the stage of formation of the innovation system, the quality of which complies with the market requirements. The task is set to make labor more intellectual, thus change the labor relations, which goes along with radical changes in the whole vital functions of companies. The innovation scope is so vast that it cannot be limited to new products and new technologies. Understanding of innovations becomes broader and is equaled to strategy. With respect to strategy, the following innovations are of importance:

\footnotetext{
${ }^{4}$ Stewart T. Intellectual capital. New source of company's wealth. M., Pokoleniye, 2007
} 
- Social innovations connected with improvement of labor conditions, social security, psychological climate and internal relations;

- Innovations in management implying improvement of the organization structure, style and methods of the decision making, usage of new information processing means;

- Innovations in planning;

- Motivational innovations;

- Innovation in control;

- Innovations in personnel training;

- Innovations in estimation and personnel placement.

The company's innovation potential is determined by elements making up its production and management system.

Figure 1: Total company potential (its main constituents)

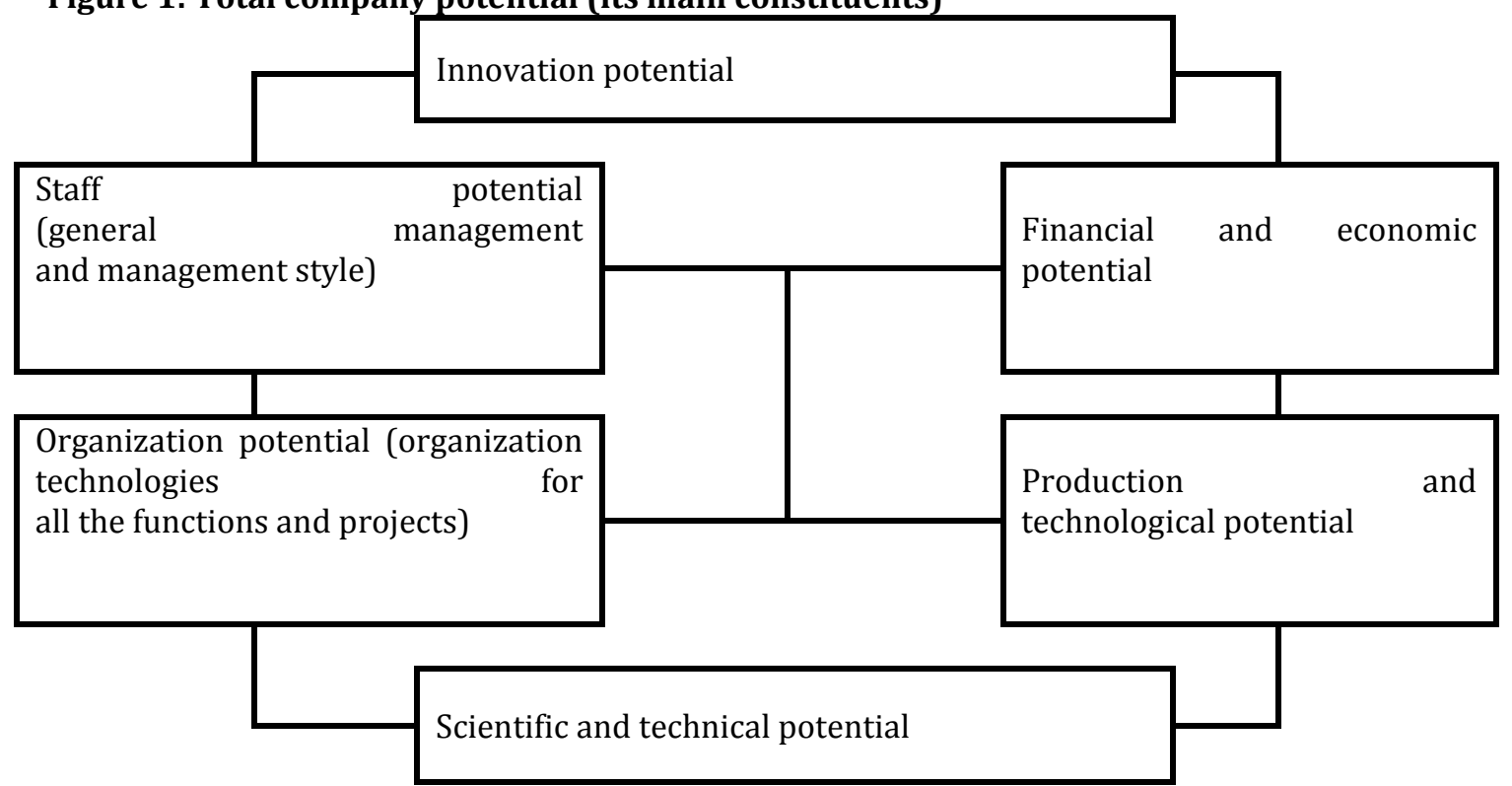

Source: “Innovation management in constitution and business" Ukolov V.F. M., Economics, 2009, p. 88.

The company total potential is based on the innovation potential, which is included in all its units. Taking into account each of the main factors makes it possible to develop scientific, organization, technological and infrastructural models of the innovation potential of the companies.

\section{Concept of Integration}

The program document on the long-term socio-economic development of Russia worked out in compliance with the assignment of the President of the Russian federation specifies that Russia should become a world leading power of the XXIst century taking advanced positions in the global economic competition. Systematic achievement of the set goal is connected with transition from exportation of natural resources to innovational and socially oriented development, where Russia is to solve simultaneously the problems of catch-up and advanced development. However, this policy is only possible in the long term. First, this process will require refreshing of the brainpower, investigation, and creative adaptation of the recent gains of the world science. Second, there will be inevitable difficulties in finding sales markets for the elaborated technologies and hi-tech products. This niche is largely occupied. We see that mines of the Kemerovo region use nowadays technologies and equipment from China. Third, our home practice lacks the culture of after sales service, which in its turn, decreases competitiveness of the products supplied. Fourth, there is a big gap between the scientific and commercial activity. Unfortunately, Russian economy is not sufficiently adapted to usage of intellectual resources as a basic production factor. The majority of managers are conservative considering further exploration of natural resources as their business development strategy. At the turn of the XX century, the share of hightechnologies in the industry output of Russia in the world commercialization was less than $1 \%$. Russian innovation products in world markets took $0,2-0,3 \%$ compared to $40 \%$ of the USA (the gap is more than 100). The years of reforms almost destroyed the main consumer of innovations - knowledge-based 
industry. For the last 40-50 years such high-technology branch as machine building has lost about 40 enterprises. Saint-Petersburg Precision Machine-Building Plant - one of two world famous enterprises which manufactured unique machines for instrument bearings - is a bright example of loss of technological and defense security. The "efficient owner" turned the plant that used to manufacture bearings for guidance systems into a ... shopping mall with a hotel on the place of the industrial buildings. In Western Europe 80\% of companies use scientific achievements compared to 5\% in Russia. The world market of information technologies approaches $\$ 1,5$ trillion, being $\$ 8$ billion in Russia (which is only $0,5 \%)$.

Russian economy is not able even to use discoveries of domestic scientists. Thus, we take the $6^{\text {th }}$ place in the world for generating ideas, patents, other objects of intellectual property and the $90^{\text {th }}$ - for the ability to make business out of that, i.e. capitalize intellectual resources. Susceptibility of the national economy to technical innovations, development of network infrastructure, as well as the level of penetration of high technologies into business and the state sector are insignificant in Russia so far, Russia does not almost export high technology products, though exports intellectual force being a "superpower" of intellectual export. Beginning from 1992, due to migration of qualified specialists Russia loses every 5-7 years one annual budget on the average only for the account of direct losses (migration of specialists abroad or shifting Russian companies to firms with participation of foreign capital). If we count the loss of profit from unimplemented ideas and estimate losses from destruction of scientific school, this figure will increase by an order. The West is interested in attracting qualified work force. Thus, involvement of one social scientist form abroad saves the USA 235 thousand dollars, an engineer - 253 thousand, a doctor 646 thousand, a specialist in engineering technology - 800 thousand. Some researches explain boom of the American Clinton economy by a mass inflow of scientists and intellectuals from the former USSR. Now in Russia there are 422 thousand scientists though in the USA there are more than 3 million. The number of scientists working for American economy increases permanently due to inflow of the "brains", mainly from Russia and CIS-member states. According to the data of the US Scientific Fund, up to $80 \%$ mathematicians and half physicists come from our country. Only in the Silicon Valley there are about 200 thousand former Soviet specialists. "Brain leakage" in Russia takes place not only abroad but within the country as well - from science to business and not necessarily domestic business. Thus, in 2004, the world giant Intel acquired two Russian high-technology companies - "Elbrus" from Moscow and "UniPro" from Novosibirsk. It is not stocks that were purchased but "brains" of Russian specialists that were taken on the staff of the American company (Gaponenko \& Orlova, 2008).

Nowadays the government of the Russian Federation is working out steps for adaptation of the industries to WTO conditions preserving the programs of financial support of the ones that are most susceptible to the new conditions. The situation is most serious for the metallurgy, extractive industries, light industry, and agro-industrial complex. The programs of government support of manufacturing of the agricultural machinery, shipbuilding, and aviation are to be transformed in accordance with the WTO norms, providing support directly to the producers. Thus, the government program of agricultural development for 2013-2020 implies financing from the federal budget at the amount of 2,28 trillion rubles. Besides, a number of administrative measures have been planned, for example, in the sphere of customs management of Russian export. The European Union assumes to cancel the quotas for Russia for supply of non-ferrous metals, increase the tariff quotas for exportation of timber and other raw materials from the date of joining to the WTO. The customs tariff for exportation of ferrous ware remains the same $-5-20 \%$ for various goods. The program provides gradual decrease of customs duties for most textile products including clothes. Most changes take place in the motor car industry. Upon Russia's joining the WTO, the duties for new cars will decrease from 30 to $25 \%$, being valid for three years from the date of joining. From the fourth to the seventh year it will decrease from $25 \%$ to $15 \%$ in equal shares. However, within 7 years prohibitive tariffs for used cars older than 7 years will remain on the same level decreasing to $20 \%$ for 3 to 7 year old cars. Duties for tractors and trucks will be partially reduced, being from $20-25 \%$ to $15 \%$ on the average for particular kinds of the vehicles. To compensate for the losses of foreign car makers who started their production in Russia, the authorities of the Russian Federation introduced the utilization fee from 1 September 2012. These fees shall be collected in the case of importation of both new and used cars. It is manufacturers and importers that are to be in charge of the utilization, which will add value to the cars and, summed up with the reduced import duties, will be similar to the previous price level.

The rates of export duties for the natural gas, oil gases, and carbohydrates in the gas state shall not be changed. The rates for the natural gas will remain at the level of $30 \%$, for the other aspects $-5 \%$ of the 
customs value. Export customs duties for oil and a number of oil products, where the rates are set by the RF government annually with the account of the average price for Urals oil at the world markets, will also remain unchanged. According to the estimates of the Ministry of Economic Development, it is only elimination of barriers for the Russian export after joining the WTO that can create up to 40 additional jobs in the country. Direct budget losses from Russia's joining the WTO can be 188 bn rubles in 2013 and 257 bn rubles in 2014, however, actually, they will be lower due to the decrease of the foreign trade volumes, collection of the duties etc. The targets of the development of the country have determined the change of the export structure and its differentiation, which is only possible subject to creation of the national innovational system. This, in its turn largely depends on activation of the innovational activity of the sides of economic relations in the country. For the enterprises involved in innovational technologies, search for sources and methods of financing of innovation projects appears to be a problem of exceptional importance. It is difficult for small and innovational businesses to attract resources due to high risks and lack of property to secure credits of commercial banks as possible investors financing innovation projects. Thus, the fastest developing business spheres based mainly on intellectual resources appear to be cut from bank credits. However, the ability of intellectual assets to be profitable is one of the conditions of involvement thereof in the economic turnover, and possible alienation of these assets to other parties by authorities of various volume and character allows for wider usage thereof in the process of increasing the company value. The variety of types of intellectual assets provides various forms of transfer thereof.

\section{Conclusion}

Investigation of the processes of integration of national economies in the world economic environment in the context of globalization allows us to reveal the factors largely determining the dynamic equilibrium with the outer environment, monitoring the demands of the latter. Nowadays, market overstocking has aggravated the competition, with modernization of national economies, which provides usage of innovational technologies and export diversification, being one of its effective instruments.

The problem for Russia is that nowadays Russia hasn't created sufficient organization and relationship capital, which makes the aggregate intellectual capital lower than it could be in the integral process.

\section{References}

Act of the Russian Federation's President about ratification protocol for joining to the Marrakesh agreement. № 126 - $\$ 3$ of 21.07.2012.

Daum, J. H. (2002). Intangible Assets. Bonn: Galileo Press Gmbh.

Roos, J., Pike, S. \& Fernstrem, L. (2008). Intellectual capital: practice of management. Saint Peterburg,"Higher School of Management.

Stewart, T. (1991) Brainpower. // Fortune. 123, 1991.

Stewart, T. (2007). Intellectual capital. New source of company's wealth. Moscow. Pokoleniye, 2007

Gaponenko A. L. \& Orlova, T. N. (2008). Knowledge management. How to turn knowledge into capital. M: Eksmo.

Ukolov, V. (2009). Innovation management in constitution and business. Moscow. Economics, 2009. 